\title{
A Recollection of Chinese Bible Translation throughout History-A Sociological Study on Translation
}

\author{
Xizhi Zhang \\ South China Business College, Guangdong University of Foreign Studies, Guangzhou, Guangdong, China

\begin{abstract}
Under the guidance of Pierre Bourdieu's reflective sociology theory with the three key concepts, 'field', 'habitus' and 'capital', the author engages in a sociological study of Chinese Bible translation over the past one thousand years by dividing the historical course of Chinese Bible translation into five stages: namely, germination, initiation, prosperity, transition and development, thus outlining the history of Chinese Bible translation.
\end{abstract}

Index Terms - sociology of translation, Bible, Chinese translation

\section{INTRODUCTION}

Since the late 1990s translatology has been influenced by sociology, especially Pierre Bourdieu's reflective sociology. Pierre Bourdieu proposed a formula: [(habitus) (capital)] plus field = practice (Bourdieu, 1984, p. 101). In order to outline the history of Chinese Bible translation, the author intends to employ the three concepts, 'field', 'habitus' and 'capital', of Pierre Bourdieu's reflective sociology in reviewing Chinese Bible translation courses, which are divided into five stages.

It is necessary to make it clear that the so-called 'Chinese translation' only involves the Han people's language, as is the common language for all Chinese nationalities; all editions in dialects, for example, Cantonese and Shanghainese or in languages of minorities, for example, the Miao language and the Yi language, are beyond this study.

\section{Chinese Bible Translation: Historical Explanations From the Perspective of the Sociology of} TRANSLATION

With the formation and development of the field of Chinese Christianity within China, translators with different identities during different historical periods over the past one thousand years took part in translating practices. Their translating practices resulted from the contemporary 'religious fields', 'commercial fields' and 'the field of power' of those periods inside or outside China and were closely related to 'cultural capital', 'economic capital' and 'social capital,' which existed in those fields. In these special circumstances the unique habitus of these translators came into being.

A. Foreign Churchmen Acting as Leading Translators (from the Tang Dynasty to the Time before and after the May 4th Movement): Chinese Bible Translation Accompanying the Religious Fields Appearing out of Nothing

Christianity is not an indigenous religion in China. It was first introduced into China during the Tang Dynasty. The Christian field experienced a long and gradual process from absence to establishment from the Tang Dynasty to the time before and after the May 4th Movement, during which foreign churchmen who lived in China acted as leading translators in the Chinese Bible translation projects.

1. Stage of germination (the Tang Dynasty): Budding Chinese Bible translation originating from the appearance of the Christian religious field

The religious field is attached to political and cultural fields. During the long period spanned by the Tang Dynasty a stable and harmonious situation remained in place. It is during this period that the Silk Road was created. The rulers of the time thus encouraged foreigners to come to China for the purpose of trade. As a result, the commercial field brought about the Christian religious field. When Christianity was first introduced into China by Alopen, the missionary, it was named Jingjiao meaning 'Bright Church' and is universally known as Nestorianism. The record on the Nestorian Stele, which was made in 781 A.D. and is now exhibited in Xi'an, depicts the thriving nature of Nestorianism in China: '法流 十道......寺满百城......' ('The creed spreads far and near ... Many cities are full of holy churches...'). This illustrates the appearance of the earliest Chinese Christian field. Since the foreign missionaries did not pay much attention to training local churchmen (Duan, 1998, p. 137), Chinese Bible Translation was carried out through foreign missionaries'oral accounts (though also drawing on the expressiveness arising from their body language) and Chinese church workers writing down the lines (Weng, 1996, p. 3). Although the Nestorian religious field was forming rapidly during this short period, it was still in the budding stage. The principal religious fields still belonged to Buddhism and 
Taoism. In early Chinese versions, many Buddhist terms were borrowed: ‘三一妙身'(three parts making up a concordant body---corresponding to 'Trinity'), “慈父阿罗诃'(Alaha, the kind father---corresponding to 'Jehovah, our heavenly Father'), “弥施诃普尊大圣子’ (the great son of the mahapa) corresponding to 'Jesus, the son of the messiah'), to name just some. This practice was primarily for the purpose of promoting the development of the Christian field in China by making the Bible easy for Chinese people to understand. Another reason was that the Chinese translators were more familiar with Buddhist terms from their previous long experiences of indulging in Buddhist-Taoist culture (Wu , 2016). Unexpectedly, owing to the action to suppress Buddhism during the reign of the Tang emperor Wuzong, Nestorian missionaries were forced to withdraw from central China. Moreover, since the Silk Road was cut off afterwards, the budding Christian field suffered severe setbacks and soon vanished in central China.

2. Stage of initiation (Late Ming Dynasty---Late 18th Century): Catholic missionaries acting as leading translators

During the 15th and 16th centuries European people succeeded in discovering the new continent and fulfilling the voyage around the world. Thereupon, a brand-new maritime navigation era began. European people started to develop a wider sphere of vision. At this time the religious field attached to the Roman Curia suffered a great blow because of the Reformation Movement in which Protestantism broke away from Catholicism and thus severely weakened the Roman Curia's orthodox dignity and glory. Catholicism thus turned its gaze towards the remote oriental world (Shang, 2017, p. 80)

In the late 16th century, missionaries of the Catholic Society of Jesus once again introduced Christianity into China. In order to win the support of the Chinese field of power, the missionaries learned Confucianism on their own initiative so as to get close to the Chinese cultural field. Their efforts made them popular with far-sighted personage. Strikingly, they managed to baptize some intelligent people like $\mathrm{Xu}$ Guangqi, Li Zhizao and Yang Tingjun (http://bbs.gxsd.com.cn/forum.php?mod=viewthread\&ordertype=1\&tid=470010). Obviously the field of power was rather tolerant of the Christian field, which offered favourable conditions for restarting Chinese Bible translation projects. Italian missionary Matteo Ricci translated and edited the main ideas of the Bible. Portuguese missionary Emmanuel Diaz translated the Four Gospels of the Bible. Early in the 18th century, French missionary Jean Basset translated Acts, The Letters of Paul and some parts of the four Gospels. At the end of the 18th century, French missionary Louis de Poirot translated The Old Testament and The New Testament, except for most of Prophets and Song of Songs.

Since translation practices took shape after the Christian field had become established in China, the versions from this period were more loyal to the original Bible version. French missionary Louis de Poirot exemplified the principle of loyalty, only intending to retain the original meaning of the Bible and ignoring readers' preferences (“不图悦人听, 惟图 保存圣经的本文文意') (Zhao, 1993, p. 15).

3. Stage of prosperity (19th Century to the time before and after the May 4th Movement): Protestant missionaries acting as the main translators

During this period, the Chinese Christian field went from operating on a small scale to a large scale, from existing only in isolated areas of the country to having a presence across entire regions. At the same time, Western capitalist countries entered a stage of rapid development during which they further strengthened their outward expansion. In the early 19th century, foreign missionaries had no freedom to preach their beliefs. Things changed in the mid-19th century when the 'Treaty of Whampoa', the 'Treaty of Tientsin' and the 'Treaty of Peking' were signed. These treaties guaranteed preaching rights for foreign missionaries and provided them with protection and convenience. Henceforth, comprehensive favourable conditions for the introduction of Christianity formed: in the commercial field, capital strengthened; in the religious field of Western countries missionary actions became more active and, above all, in the Chinese field of power an unprecedentedly tolerant attitude toward the cause of local Chinese Christianity appeared. All of these factors helped the Chinese Christian field prosper and allowed Chinese Bible translation to develop and thrive.

From the perspective of translators' habitus, since Protestantism pays greater attention to establishing relations between believers and God by each believer reading the Bible and praying, Protestant missionaries were more focussed on Bible translation. Thus, many Chinese versions of the Bible appeared during this period. Over a period of one hundred years - from 1819, when the British missionary Robert Morrison completed the first Chinese cover-to-cover translation of the Bible, to 1919-nine cover-to-cover translated versions in all appeared; in contrast, no Catholic cover-to-cover Chinese translated version appeared until 1968. In terms of lingual styles, the above nine versions can be classified into three types: contemporarily vernacular versions, semi-classical versions and classical versions. Obviously, the Chinese Bible versions appearing in this period were unprecedented, many in terms of both quantity and variety. And the translation projects in this period were carried out under more careful organization than ever before. For example, the translating practice of the British missionary William Milne and his assistants was the direct mission assigned by the London Missionary Society. In 1890, a missionary conference was held in Shanghai. During the meeting, deputies from different churches formed three commissions, each in charge of one of the three versions: the Chinese Union Version (CUV) (contemporarily vernacular), Easy Wenli Union Version (semi-classical versions) and High Wenli Union Version (classical).

A notable fact is that the British missionary Robert Morrison's completion of his cover-to-cover Chinese Bible translation resulted solely from his habitus, the related fields and the fund supporting him. Morrison was to become a famous sinologist. He began learning Chinese early on in his schooling. As a grown-up, he became a member of the 
Presbyterian Church and was sent to China for missionary work. Clearly, his education and his belief in doing service to God shaped the formation of his habitus as a translator. Before he went to China, he once asked somebody to copy French missionary Jean Basset's Chinese translation of the Bible, with which he continued to learn Chinese. This fact shows that he benefited from the Catholic field. Since the Qing government did not allow foreign missionaries to go to inland areas at that time, he had to dwell in Macao in order to undertake his great Bible translation project; (Macao was, at this time, under Portuguese administration and thus not subject to the Qing government's decrees, allowing it to have an unconfined religious field). His translation was published in Malacca and subsequently introduced into China. From then onwards, Chinese people could read the whole of the Bible.

A full set of Christian terms were created in Morrison's translation, which deeply influenced later generations. His translated version caused a sensation in Europe. Leading European libraries viewed it as an honour to possess his translated Bible (Tan, 2000). It is his translated version that established his status and honour, which can be considered as social capital, in Christian fields in China and even throughout the world. In turn, his social capital increased his cultural capital. Therefore, under the invitation of business circles, he opened the London Oriental Institution, in which Chinese lessons were provided (Ch'en \& Hsiao, 1967, p.2). Consequently, in running this institution, which had resulted from the stimulation of economic capital in the commercial field, Morrison accumulated a lot of cultural capital for his sinological field in Britain.

Another aspect worthy of consideration is that foreign missionaries' habituses, embodied in their translation, played a role within the Chinese Christian field. In addition to early publishing, initiated by Morrison, a missionary conference held in 1877 gave birth to a commission on schooling and course books. This commission's goal was, initially, to compile course books for church-run schools. It subsequently developed to become the largest publisher in the country, named 'The Christian Literature Society for China', in which many Christian sects participated. This society published large quantities of Christian Gospel and Spirituality books, as well as books introducing Western science and technology. Tian Feng, the journal published by the National Committee of the Three-Self Patriotic Movement of the Protestant Churches in China ('National TSPM') was also issued by this society before May 1957.

\section{B. Chinese People (Churchmen) Acting as Leading Translators (1920's --- Present Time): Systematic Chinese Translation after the Establishment of the Christian Field}

The 20th century witnessed the overall localization of the Chinese Christian field. At the beginning of the 20th century, the Boxer Rebellion and the conflicts that emerged between China and foreign countries led to an upsurge of national pride among Chinese Christians. Accordingly, a self-governing church movement boomed (Zhang, 1998). Within this movement, the famous Chinese Presbyterian pastor Yu Guozhen (from Shanghai) founded the China Christian Independent Church. Notably, a talent pool for Chinese Bible translation projects appeared as a result.

1. Stage of transition (1920s --- late 1970s): Chinese translators starting their translation

During this period, changes began to manifest themselves in terms of the nationalities of translators. When Chinese Bible translation began, foreign missionaries played the leading role and their Chinese colleagues acted as assistants. Later on, they would reverse roles, with foreign missionaries assisting Chinese translators in the translation projects. Furthermore, Chinese translators eventually undertook this work on their own.

In 1935, Italian Rev. Gabriele Allegra began his Bible translation. He completed translating the Old Testament in 1944. However, he felt it necessary to modify his translation. So he founded an association, i.e. a branch of the Studium Biblicum Franciscanum in Peking in 1945 for the purpose of pooling translation talent to perfect the quality of the translated text. This association consisted of Chinese priests, among which were Rev. Li Shiyu and Rev. Li Zhixian as formal members and Rev. Wan Cizhang, Rev. Li Yutang and Rev. Liu Xutang as informal members. In 1948, with the increasingly tense situation of the Chinese civil war, the Chinese Christian field — in which foreigners participated — was confronted with negative factors. Therefore, this association transferred to Hong Kong and continued the translation project. In this project, the revision of the New Testament was in the charge of Rev. Li Shiyu. This revised version, known as the Studium Biblicum Version (Catholic), was finally published in 1968.

During this period, the translation that was carried out solely by a Chinese translator was Lu Zhenzhong (吕振中)'s Bible Translation. Lu Zhenzhong was born into a Christian family in Fujian Province, adopting Christianity during his childhood and attending Peiyuan Middle School, a church school. Subsequently, he obtained a Bachelor of Arts degree at the University of Hong Kong. Later, he studied at Yenching University, which was run by four American and British Christian churches, and obtained degree in theology. In 1940, he began translating the Bible at Yenching University's School of Religion. It is clear that Lu Zhenzhong's translator's habitus was heavily shaped by the fact that his family had been steeped in the Christian tradition throughout his formative years, and his education had an entirely Christian foundation. In order to prepare himself for translating the Bible, he went first to America and then to Britain in order to learn theology, Greek and Hebrew. During those years, he attained a Master of Divinity degree in America and was ordained a priest in Britain. Favourable Christian fields with abundant cultural capital in America and Britain immensely promoted his Bible translation. In March, 1949, Rev. Lu transferred to Hong Kong to continue his translating work with the financial aid of the British and Foreign Bible Society due to the fact that the field of power in the Chinese hinterland was becoming more and more unfavourable for the existence and development of the religious field. Rev. Lu's translation, the Lu Zhen Zhong Bible Translation, was finally published at the end of 1970. A great 
30-year-long project was completed at last.

2. Stage of development (1980s --- Early 21st Century): systematic translation by Chinese people of different nationalities

At the beginning of the 1980s China began to get rid of the influence of the disastrous so-called Cultural Revolution; the field of power was no longer blatantly hostile towards Western countries, nor did it suppress different religions anymore. Instead, it began to implement a policy of openness and gradually developed a newly tolerant attitude towards foreign religions. With China's process of reform and opening up further developing, the relatively tolerant field of power made it possible for the Christian field to recover. Churches and other prayer meeting venues, which had once been unwillingly closed and forcibly occupied for other uses, eventually resumed their original functions. At the same time, mainland Chinese Christians regained opportunities to exchange and cooperate with other Christian workers from outside the Chinese mainland. Thus, the mainland Chinese Christian field regained access to the Christian fields beyond the Chinese mainland and could once again employ their rich cultural capital and economic capital for Chinese Bible translation. Over the past thirty years, Chinese Bible translation has been mainly carried out — on a systematic basis—by trans-national or trans-regional Chinese organizations. The United Bible Societies, Hong Kong Bible Society and Chinese Bible International LTD made outstanding contributions to these projects.

The United Bible Societies (UBS), composed of Bible societies of different countries, is responsible for coordinating Bible translations in different languages and different versions. In 1987, the UBS and the leaders of Chinese Christianity negotiated the setting up of a Bible printing house in Nanjing. In 1988, the UBS published the Holy Bible Chinese Union Version with New Punctuation. This new version is the revised edition based on the previous Chinese Union Version, with some expressions, paragraphs and punctuations having been modified. In addition, the Hong Kong Bible Society, affiliated with the International Bible Society, published the Chinese Union Version Bible 2010. This version was completed by a group composed of ethnic Chinese scholars and pastors from the Chinese mainland, Hong Kong, Macao and various Southeast Asian countries. The series of translations, which began in the 1980s, embraced previously published versions, i.e. The New Testament (the Revised Chinese Union Version) (2006) and The Old and New Testaments (Revised Chinese Union Version) (2011). This edition embodies the norms of the modern Chinese language, with a plainer and more natural-sounding vocabulary (Chinese Christianity Network, 2018).

\section{CONCLUSION}

This article has revealed the historical processes of Chinese Bible translation from the perspective of Socio-translation Studies. It is more than one thousand years since the Bible was translated into Chinese for the first time during the Tang Dynasty. The history of Chinese Bible translation manifests a number of changes. One is the change of key actors --- from foreign missionaries to Chinese disciples; the other is the change of organization forms --from non-organized individuals to funded organizations. In his study on thinking and art works, Bourdieu points out that 'Research must relate the particular field of practices to the broader field of power' (Swartz, 1997, p. 142). These changes happening within the processes of Chinese Bible translation correspond to the ups and downs of the Chinese Christian field and reflect in particular the relationship between the religious field and the field of political power.

From the perspective of the theories on fields and translators' habitus, a translator's habitus results from the joint influence of different fields. In other words, a translator's ability in his/her mother language and one or more foreign language(s) determines his/her lingual habitus; in the case of translators who translated the Bible into Chinese, their religious habitus resulted from their original religious field and the subsequent Chinese religious field. The combination of these two habituses formed their translator's habitus vis-à-vis Chinese Bible translation.

Meanwhile, the translator's translating habitus, in turn, affects the fields with which he/she is associated. For example, Morrison's translation brought about striking changes in the Chinese Christian field by introducing a large quantity of Christian terms to fill the vacancies in this regard. Since the beginning of the 21 st century, with their modern lingual norms featuring plain writings in the vernacular, new Chinese versions of the Bible have also changed the Chinese Christian field in terms of structure of membership, having absorbed more and more believers from poorly-educated strata.

\section{APPENDIX}

A. Habitus 'designates a way of being, a habitual state (especially of the body) and, in particular, a disposition, tendency, propensity, or inclination' (Bourdieu, 1977, p. 214). Bourdieu also uses the wording 'cultural unconscious', 'habit-forming force' and so on to designate its concept (Swartz, 1997, p. 101).

B. There are three forms of capital: economic capital, cultural capital and social capital. Economic capital can be directly converted into currency, including wealth, income, property, etc. Cultural capital includes culture, knowledge, educational credentials, etc. which can be converted into economic capital under certain conditions. Social capital is a 'capital of social connections, honourability and respectability' (Bourdieu, 1984, p. 122) that can also be converted into economic capital under certain conditions.

C. Field is 'a network, or configuration, of objective relations between positions' (Bourdieu \& Wacquant, 1992, p. 97). The most important field is the field of power. On the one hand, it is a sort of 'meta-field that operates as an 
organizing principle of differentiation and struggle throughout all fields'; on the other hand, the field of power can be regarded as 'the dominant social class' (Swartz, 1997, p. 136).

\section{ACKNOWLEDGEMENTS}

This paper results from the relevant research supported by the subprojects of 'The Training for China Accreditation Test for Translators and Interpreters' and 'The Association Project of Comparative Study of English and Chinese in the New Era' (Ref: South China Business College 2017298), which belong to the project of Guangdong Key Characteristic Discipline (English Language and Culture) ([2017]No. 1), the Project of Guangdong University Students' Training in Entrepreneurship and Innovation: 'A Study of the Application of Trados, the Translation Software, for Cultivating Translation Professionals, Taking South China Business College, Guangdong University of Foreign Studies for Example' (Ref: 201812620011), the Project of South China Business College, Guangdong University of Foreign Studies: 'Adaptive study on reform in teaching undergraduate Students in the World-English Era' (Ref: 2017JG09) and A project authorized by School of English Language and Culture, South China Business College, Guangdong University of Foreign Studies: 'An Empirical Study of Innovative Tactics of Computer Auxiliary Translation Technology for Training Professionals in the Translation Major in Undergraduate Education, Taking South China Business College, Guangdong University of Foreign Studies for Example' (Ref: 201802).

The author wishes to thank Associate Professor Binghua Lv, Mr. Baoyu Zhang and Mr. Aidan Cowlard Joyce for their invaluable comments.

\section{REFERENCES}

[1] Bourdieu, Pierre. (1984). Distinction: A Social Critique of the Judgment of State. Cambridge: Harvard University Press.

[2] Bourdieu, Pierre. (1992). The Logic of Practice. Chicago: Stanford University Press.

[3] Bourdieu, Pierre \& Wacquant, L. (1992). An Invitation to Reflexive Sociology. Chicago: The University of Chicago Press.

[4] Bourdieu, Pierre. (1977). Outline of a Theory of Practice. Cambridge: Cambridge University Press.

[5] Ch'en, Yao-sheng \& Paul S. Y. Hsiao. (1967). Sinology in the United Kingdom and Germany. Honolulu: East-West Center.

[6] Chinese Christianity Network. The Revised Union Version. (2010). http://www.ccctspm.org/bookinfo/87 (accessed 26/05/2018).

[7] Duan, Qi. (1998). A study of localisation of churches from perspective of the history of Christianity in China. Studies in World Religions, 1, 137-141.

[8] Shang, Feng. (2017). The diffusion and influence of Catholicism in Vietnam in the 16th-19th centuries. Southeast Asian and South Asian Studies, 1, 80-85+110.

[9] Swartz, David. (1997). Culture and Power: The Sociology of Pierre Bourdieu. Chicago: The University of Chicago Press.

[10] Swartz, David. Tao, Dongfeng (Trans.). (2012). Culture and Power: The Sociology of Pierre Bourdieu. Shanghai: Shanghai Century Publishing Group.

[11] Tan, Shulin. (2000). On Marrison's translation of Bible and its influence. Journal of Shandong Normal University (Humanities and Social Sciences), 5, 60-64.

[12] Weng, Shaojun. (1996). Explanatory Notes of Nestorianist Classics in Chinese. Beijing: SDX Joint Publishing Company.

[13] Wu, Baoluo. Brief Biographies of Missionaries in North China Olopen. The Gospel Times. http://www.gospeltimes.cn/index.php/portal/article/index/id/34058 (accessed 16/06/2016).

[14] Zhang, Hua. (1998). A review of China Christian Independent Church. Hiastorical Review, 1, 57-66.

[15] Zhao, Weiben. (1993). Tracing to the Source of the Bible Translation --- A History of the Five Major Modern Chinese Translations of the Bible. Hong Kong: China Graduate School of Theology.

Xizhi Zhang is a lecturer at South China Business College, Guangdong University of Foreign Studies. Her research interests are translation and culture, translation methodology and practice. 